\title{
Data report: relative abundance of benthic foraminiferal morphotypes across the Eocene/Oligocene and Oligocene/Miocene boundaries (IODP Expedition 342 Site U1406, North Atlantic) ${ }^{1}$
}

\author{
Kazuyoshi Moriya ${ }^{2}$ and Oliver Friedrich ${ }^{3}$
}

\section{Chapter contents}

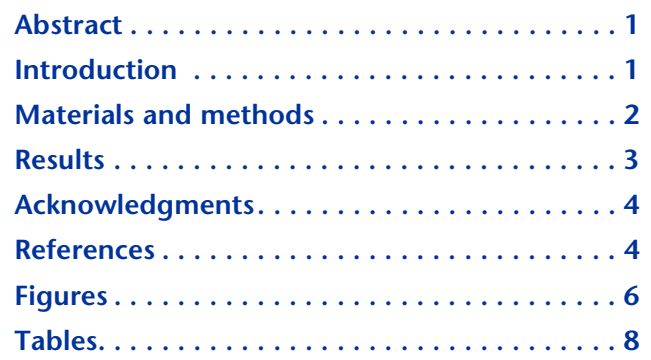

\section{Abstract}

Relative abundances of five benthic foraminiferal morphotype groups (i.e., agglutinated, elongated, planispiral, tapered, and trochospiral) from the late Paleocene to early Miocene at Site U1406 (Integrated Ocean Drilling Program Expedition 342) are reported. Benthic foraminiferal tests from Site U1406 are generally very well preserved and occur abundantly from the late Eocene through middle Oligocene; they are less abundant for the remainder of the studied interval. Among the five morphotypes identified in this study, tapered and trochospiral forms are the dominant groups. Thereby, tapered morphotypes show increasing abundances at and above the Eocene/Oligocene and Oligocene/ Miocene boundaries. Agglutinated and planispiral morphotypes are minor components throughout the studied interval. Relative abundances of the elongated morphotype abruptly increase during the lower Eocene. This increase can be correlated to a distinct decrease in carbonate content between lithostratigraphic Units III and IV.

\section{Introduction}

Because of the relatively stable and monotonous deep-sea environment, the stratigraphic range of benthic foraminiferal species is relatively long, and their usefulness for biostratigraphy is less advantageous compared to planktonic foraminifers (e.g., Boltovskoy, 1980; van Morkhoven et al., 1986; Thomas, 2007). On the other hand, benthic foraminiferal species provide useful indicators of environmental change, and significant changes in benthic foraminiferal assemblage composition usually imply severe climatic and/or paleoceanographic perturbations (e.g., in global ocean circulation). One of the most severe perturbations occurred across the Paleocene/Eocene boundary accompanied by a major redistribution of benthic foraminiferal faunas (e.g., Kennett and Stott, 1991; Thomas and Shackleton, 1996).

Following this major turnover across the Paleocene/Eocene boundary, three benthic foraminiferal faunas can be recognized: (1) Paleogene-like fauna during the Eocene, (2) transitional fauna in the late Oligocene to early Miocene, and (3) near-modern-like faunas that developed from the late Miocene onwards (Thomas, 1992, 2007). These three different faunas are separated by faunal turnovers associated with the global cooling event at the Eocene/ 
Oligocene boundary and the middle Miocene climatic optimum.

Although morphotypes of benthic foraminifers do not exclusively represent ecology and/or habitat of a given species, it has been reported that changes in morphotype composition and/or the reaction of specific morphotypes are related to environmental perturbations (e.g., Rosoff and Corliss, 1992). One example for this pattern is the significant decrease of elongated morphotypes, such as pleurostomellids and stilostomellids, across the Eocene/Oligocene boundary and during the middle Miocene turnover (e.g., Thomas, 2007). This pattern suggests the response of a specific morphotype, and therefore a specific habitat, to climate perturbations. Relative changes in the abundances of benthic foraminiferal morphotypes may therefore represent faunal turnover and/or climate variation.

Integrated Ocean Drilling Program (IODP) Expedition 342 recovered semicontinuous sequences from the Lower Cretaceous to middle Miocene. Especially for the lower Eocene through lower Miocene interval, many continuous cores containing well-preserved microfossils were drilled at multiple sites (see the "Expedition 342 summary" chapter [Norris et al., 2014a]).

Among those sites, coring at Site U1406 recovered carbonate-rich sediments of late Paleocene through early Miocene age, including the Eocene/Oligocene and Oligocene/Miocene boundaries (see the "Site U1406" chapter [Norris et al., 2014c]).

In this data report, we present changes of benthic foraminiferal morphotype distribution across these cooling events at Site U1406.

\section{Materials and methods}

\section{Site studied}

Site U1406 $\left(40^{\circ} 21.0^{\prime} \mathrm{N}, 51^{\circ} 39.0^{\prime} \mathrm{W}\right)$ was drilled at $\mathrm{J}$ Anomaly Ridge, southeast of Newfoundland in the northern Atlantic (Fig. F1) in a present water depth of $3798.9 \mathrm{~m}$ (see the "Expedition 342 summary" chapter [Norris et al., 2014a]). Three holes were drilled at this site, recovering $\sim 310 \mathrm{~m}$ of sedimentary sequences. The sequences were divided into lithostratigraphic Units I through IV. Units I and II are composed of foraminiferal sand and/or nannofossil ooze (see the "Site U1406" chapter [Norris et al., 2014c]). Units III and IV mainly consist of nannofossil chalk. The uppermost Unit I is correlated to the Pleistocene (0-2.61 m core composite depth below seafloor [CCSF] in Hole U1406A). Unit II (2.61$205.68 \mathrm{~m}$ CCSF in Hole U1406A) is Oligocene through Miocene in age, including the Oligocene/
Miocene boundary (88.09 m CCSF). Unit III correlates to the middle Eocene through early Oligocene (206.68-273.84 $\mathrm{m}$ CCSF in Hole U1406A) and includes the Eocene/Oligocene boundary $(\sim 219 \mathrm{~m}$ CCSF). The deepest Unit IV (273.84-310.83 m CCSF in Hole U1406A) represents the Paleocene to middle Eocene time interval with a significant hiatus during the early Eocene. Carbonate content is generally more than $40 \mathrm{wt} \%$ in all units, indicating that the site was positioned above the carbonate compensation depth throughout it sedimentary history (Fig. F2) (see the "Site U1406" chapter [Norris et al., 2014c]).

Sedimentation rate at Site U1406 is somewhat higher than normal deep-sea sediments because of the site's position in a drift. Sedimentation rates are especially high within Unit II, where they are estimated to be $\sim 2.8 \mathrm{~cm} / \mathrm{ky}$. Downhole, sedimentation rates gradually decrease and are $\sim 0.6 \mathrm{~cm} / \mathrm{ky}$ across the Eocene/ Oligocene boundary, $\sim 0.2 \mathrm{~cm} / \mathrm{ky}$ in the early Eocene, and somewhat higher at $\sim 0.8 \mathrm{~cm} / \mathrm{ky}$ within the $\mathrm{Pa}-$ leocene. Mass accumulation rates are $\sim 0.5-1.0 \mathrm{~g} /$ $\mathrm{cm}^{2} / \mathrm{ky}$ in the early Miocene through late Eocene except for the late Oligocene and the Oligocene/Miocene boundary where they reach $1.5-2.0 \mathrm{~g} / \mathrm{cm}^{2} / \mathrm{ky}$ (see the "Site U1406" chapter [Norris et al., 2014c]).

\section{Samples analyzed}

Core composite depth of each core and sample was calculated based on the splice table published by Norris et al. (see Table T21 in the "Site U1406" chapter [Norris et al., 2014c]). All samples analyzed in this study were taken from Hole U1406A. Top core composite depth of each core from Hole U1406A was also calculated and is graphically shown in Figure F2.

In addition to the core catcher samples taken on the catwalk, $\sim 5 \mathrm{~mL}$ discrete section samples were examined. A list of all samples studied is shown in Table T1. Samples were taken, on average, every $3 \mathrm{~m}$, and 102 samples were analyzed in total from Cores 342U1406A-1H through 34X. For cores recovered with the extended core barrel, a relatively well preserved solid piece of sediment was chosen for the discrete sampling.

Samples were prepared following the procedure described in detail in the "Methods" chapter (Norris et al., 2014b). Sediments were washed with tap water over a $63 \mu \mathrm{m}$ sieve. If necessary, samples were washed and dried repeatedly until the fine fraction was thoroughly removed. Subsequently, all washed samples were oven-dried at low temperature $\left(\sim 50^{\circ} \mathrm{C}\right)$ and examined under a binocular microscope. Benthic foraminifers were hand-picked from the $>150$ $\mu \mathrm{m}$ size fraction. Relative abundances of benthic for- 
aminiferal morphotypes are based on counts of $\sim 100$ individuals from each sample (mean value; maximum 385 individuals, minimum 19 individuals; see Table T1). When the number of benthic foraminiferal specimens was $<100$ in a given sample, all individuals from the $>150 \mu \mathrm{m}$ size fraction were analyzed.

Five benthic foraminiferal morphotypes were identified in this study:

1. Agglutinated $=$ all specimens with agglutinated tests.

2. Elongated $=$ uniserial elongated morphology with calcareous tests.

3. Planispiral $=$ planispiral morphology with calcareous tests.

4. Tapered = multiserial, unilocular, ovate, and quinqueloculine morphology with calcareous tests.

5. Trochospiral $=$ trochospiral morphology with calcareous tests.

The dominant species for each morphotype are listed in Table T2. Please note that all specimens with an agglutinated test wall are assigned to the agglutinated morphotype.

\section{Results}

\section{Abundance and preservation}

Group abundance, preservation, and total number of benthic foraminiferal specimens examined in each sample are shown in Figure F2. Whereas total number of specimens examined is typically $~ 100-150$ from Samples 342-U1406A-1H-CC (6.23 m CCSF) through 26X-CC (246.36 m CCSF), the number decreases downhole. The scarcity in benthic foraminifers is also seen in the group abundance (Fig. F2), which is due to the increasing abundance of planktonic foraminifers in carbonate-rich sediments of lithostratigraphic Units III and IV (Fig. F2) (see the "Site U1406" chapter [Norris et al., 2014c]). Carbonate content significantly decreases at $\sim 270$ m CCSF, and benthic foraminiferal group abundance increases uphole from $\sim 260 \mathrm{~m}$ CCSF to the seafloor. Group abundance shows the highest values between 120 and $250 \mathrm{~m}$ CCSF. The preservation of benthic foraminifers seems to be affected by the carbonate content as well. Whereas moderate or poor preservation is occasionally found in samples deeper than $250 \mathrm{~m} \mathrm{CCSF}$, the preservation is predominantly very good in shallower samples. Because cores shallower than $250 \mathrm{~m}$ CCSF contain less carbonate and more clay minerals (see the "Site U1406" chapter [Norris et al., 2014c]), the preservation of benthic foraminifers seems to be enhanced in the less permeable clay- rich sediments. On the other hand, in carbonate-rich deeper cores, precipitation of secondary calcite overgrowth has often been found.

\section{Relative abundance of benthic morphotypes}

Among the five different benthic foraminiferal morphotypes identified, trochospiral is the dominant type throughout the studied interval (Fig. F2). In contrast, the planispiral morphotype is the least abundant, with values usually $<10 \%$ (average = 5.9\%). Agglutinated foraminifers are also a minor constituent of the investigated faunas, showing average and maximum abundances of $7.7 \%$ and $27.3 \%$, respectively. Compared to the agglutinated and planispiral morphotypes, elongated and tapered forms are relatively abundant, and their abundance is characterized by large variability downhole (Fig. F2). Thereby, maximum abundances are $68.8 \%$ for the elongated morphotype and $57.8 \%$ for the tapered morphotype.

Deeper than $239 \mathrm{~m}$ CCSF (except for samples between 267 and $272 \mathrm{~m} \mathrm{CCSF),} \mathrm{the} \mathrm{trochospiral}$ morphotype is especially abundant ( $>40 \%)$, whereas tapered morphotype abundance is low. In Samples 342-U1406A-28X-4, 100-102 cm (267.30 m CCSF), 28X-6, 100-102 cm (270.30 m CCSF), and 28X-CC (271.69 $\mathrm{m}$ CCSF), the elongated morphotype suddenly becomes very abundant and reaches $68.8 \%$ of the studied fauna, which is the highest value throughout the studied interval. In parallel, the trochospiral and tapered morphotypes decrease to $<20 \%$. This drastic change in relative abundances can be correlated to an abrupt decrease in carbonate content (Fig. F2). Whereas carbonate content between 280 and $310 \mathrm{~m}$ CCSF is usually $>80 \mathrm{wt} \%$, it decreases rapidly between 270 and $280 \mathrm{~m}$ CCSF, reaching $\sim 50 \mathrm{wt} \%$ at $260 \mathrm{~m}$ CCSF. The observed increase of the elongated morphotype occurs parallel to this drop in carbonate content. However, whereas carbonate content stays low uphole ( 40-60 wt $\%)$, the relative abundances of trochospiral and tapered morphotypes rapidly increase around 260 m CCSF, adding to $\sim 80 \%$ of the entire fauna.

At $\sim 220 \mathrm{~m} \mathrm{CCSF}$, which is correlated to the Eocene/ Oligocene boundary, abundance of the tapered morphotype significantly increases, mainly driven by the abundant occurrence of Cassidulina spp. (see the "Site U1406" chapter [Norris et al., 2014c]). High abundances of the tapered morphotype occur uphole to $130 \mathrm{~m} \mathrm{CCSF}$, well into the late Oligocene. Across the Eocene/Oligocene boundary, the observed increase in the tapered morphotype is accompanied by a rapid increase in carbonate content ("carbonate overshot"; Coxall et al., 2005) followed by a drop in 
carbonate content to $\sim 40 \mathrm{wt} \%$. Although a significant increase of the elongated morphotype is identified across the carbonate decrease event at $\sim 270 \mathrm{~m}$ CCSF, no significant increase of this morphotype is found across the Eocene/Oligocene boundary at Site U1406. In contrast, Ortiz and Kaminski (2012) reported an abrupt and short-lived increase of the elongated morphotype (mostly stilostomellids) at the Eocene/Oligocene boundary at Ocean Drilling Program Site 647 in the southern Labrador Sea. This apparent discrepancy may be related to the relatively lower sample resolution of this study. Shallower than $\sim 130 \mathrm{~m}$ CCSF, the trochospiral morphotype becomes the dominant morphotype uphole to $\sim 90 \mathrm{~m}$ CCSF, which can be correlated to the late Oligocene. The abundance of trochospiral forms decreases at $\sim 90 \mathrm{~m}$ CCSF. Interestingly, the tapered morphotype also increases at $290 \mathrm{~m} \mathrm{CCSF}$, which is correlated to the Oligocene/Miocene boundary. Cassidulina spp., which is the most significant component of the tapered morphotype (Table T1), becomes abundant again in the lower Miocene.

Although the relative abundances of each benthic foraminiferal morphotype vary with carbonate content, abundance seems to be independent of primary production. This is shown by the lack of response in morphotype abundances between 10 and $150 \mathrm{~m}$ CCSF, an interval characterized by high abundances of diatoms and radiolarians, probably indicating enhanced primary production (see the "Site U1406" chapter [Norris et al., 2014c]).

\section{Acknowledgments}

We are grateful to Richard D. Norris (Scripps Institution of Oceanography, University of California, San Diego) and Paul A. Wilson (National Oceanography Centre, University of Southampton) for their leadership and guidance during and after International Ocean Drilling Program (IODP) Expedition 342. We also thank Peter Blum for his effort to maximize our achievement and all other scientists and crew members of Expedition 342 for their help and support. We thank Michael A. Kaminski (KFUPM) for useful comments that significantly improved the manuscript. Samples and data were provided by IODP. Funding was provided by DFG grant OF 2544/2 to O. Friedrich and by Waseda University Grant for Special Research Projects (2015S-030 and 2015B-118) and JSPS KAKENHI Grant Number JP16H04070 to K. Moriya.

\section{References}

Boltovskoy, E., 1980. On the benthonic bathyal-zone foraminifera as stratigraphic guide fossils. Journal of Foraminiferal Research, 10(3):163-172. http://dx.doi.org/ 10.2113/gsjfr.10.3.163

Coxall, H.K., Wilson, P.A., Pälike, H., Lear, C.H., and Backman, J., 2005. Rapid stepwise onset of Antarctic glaciation and deeper calcite compensation in the Pacific Ocean. Nature, 433(7021):53-57. http://dx.doi.org/ 10.1038/nature03135

Kennett, J.P., and Stott, L.D., 1991. Abrupt deep-sea warming, paleoceanographic changes and benthic extinctions at the end of the Palaeocene. Nature, 353(6341):225-229. http://dx.doi.org/10.1038/ $353225 \mathrm{a0}$

Norris, R.D., Wilson, P.A., Blum, P., Fehr, A., Agnini, C., Bornemann, A., Boulila, S., Bown, P.R., Cournede, C., Friedrich, O., Ghosh, A.K., Hollis, C.J., Hull, P.M., Jo, K., Junium, C.K., Kaneko, M., Liebrand, D., Lippert, P.C., Liu, Z., Matsui, H., Moriya, K., Nishi, H., Opdyke, B.N., Penman, D., Romans, B., Scher, H.D., Sexton, P., Takagi, H., Turner, S.K., Whiteside, J.H., Yamaguchi, T., and Yamamoto, Y., 2014a. Expedition 342 summary. In Norris, R.D., Wilson, P.A., Blum, P., and the Expedition 342 Scientists, Proceedings of the Integrated Ocean Drilling Program, 342: College Station, TX (Integrated Ocean Drilling Program). http://dx.doi.org/10.2204/

iodp.proc.342.101.2014

Norris, R.D., Wilson, P.A., Blum, P., Fehr, A., Agnini, C., Bornemann, A., Boulila, S., Bown, P.R., Cournede, C., Friedrich, O., Ghosh, A.K., Hollis, C.J., Hull, P.M., Jo, K., Junium, C.K., Kaneko, M., Liebrand, D., Lippert, P.C., Liu, Z., Matsui, H., Moriya, K., Nishi, H., Opdyke, B.N., Penman, D., Romans, B., Scher, H.D., Sexton, P., Takagi, H., Turner, S.K., Whiteside, J.H., Yamaguchi, T., and Yamamoto, Y., 2014b. Methods. In Norris, R.D., Wilson, P.A., Blum, P., and the Expedition 342 Scientists, Proceedings of the Integrated Ocean Drilling Program, 342: College Station, TX (Integrated Ocean Drilling Program). http://dx.doi.org/10.2204/iodp.proc.342.102.2014

Norris, R.D., Wilson, P.A., Blum, P., Fehr, A., Agnini, C., Bornemann, A., Boulila, S., Bown, P.R., Cournede, C., Friedrich, O., Ghosh, A.K., Hollis, C.J., Hull, P.M., Jo, K., Junium, C.K., Kaneko, M., Liebrand, D., Lippert, P.C., Liu, Z., Matsui, H., Moriya, K., Nishi, H., Opdyke, B.N., Penman, D., Romans, B., Scher, H.D., Sexton, P., Takagi, H., Turner, S.K., Whiteside, J.H., Yamaguchi, T., and Yamamoto, Y., 2014c. Site U1406. In Norris, R.D., Wilson, P.A., Blum, P., and the Expedition 342 Scientists, Proceedings of the Integrated Ocean Drilling Program, 342: College Station, TX (Integrated Ocean Drilling Program). http://dx.doi.org/10.2204/ iodp.proc.342.107.2014

Ortiz, S., and Kaminski, M.A., 2012. Record of deep-sea, benthic elongate-cylindrical foraminifera across the 
Eocene-Oligocene Transition in the North Atlantic Ocean (ODP Hole 647A). The Journal of Foraminiferal Research, 42(4): 345-368. http://dx.doi.org/10.2113/ gsjfr.42.4.345

Rosoff, D.B., and Corliss, B.H., 1992. An analysis of Recent deep-sea benthic foraminiferal morphotypes from the Norwegian and Greenland Seas. Palaeogeography, Palaeoclimatology, Palaeoecology, 91(1-2):13-20. http:// dx.doi.org/10.1016/0031-0182(92)90028-4

Thomas, E., 1992. Cenozoic deep-sea circulation: evidence from deep-sea benthic foraminifera. In Kennett, J.P., and Warnke, D. (Eds.), The Antarctic Paleoenvironment: A Perspective on Global Change. Antarctic Research Series, 56:141-165. http://onlinelibrary.wiley.com/doi/ 10.1029/AR056p0141/summary

Thomas, E., 2007. Cenozoic mass extinctions in the deep sea: what disturbs the largest habitat on Earth? In Monechi, S., Coccioni, R., and Rampino, M.R. (Eds.), Large Ecosystem Perturbations: Causes and Consequences.
Special Paper-Geological Society of America, 424:1-23. http://dx.doi.org/10.1130/2007.2424(01)

Thomas, E., and Shackleton, N.J., 1996. The PalaeoceneEocene benthic foraminiferal extinction and stable isotope anomalies. In Knox, R.W.O'B., Corfield, R.M., and Dunay, R.E. (Eds.), Correlation of the Early Paleogene in Northwest Europe. Geological Society Special Publication, 101(1):401-441. http://dx.doi.org/10.1144/

GSL.SP.1996.101.01.20

van Morkhoven, F.P.C.M., Berggren, W.A., Edwards, A.S., and Oertli, H.J., 1986. Cenozoic cosmopolitan deep-water benthic foraminifera. Bulletin des centres de recherches Exploration-production Elf-Aquitaine: Mémoire, 11.

Initial receipt: 31 March 2016

Acceptance: 15 September 2016

Publication: 16 December 2016

MS 342-204 
Figure F1. A. Location of J-Anomaly Ridge and Site U1406. B. Black rectangle in A.

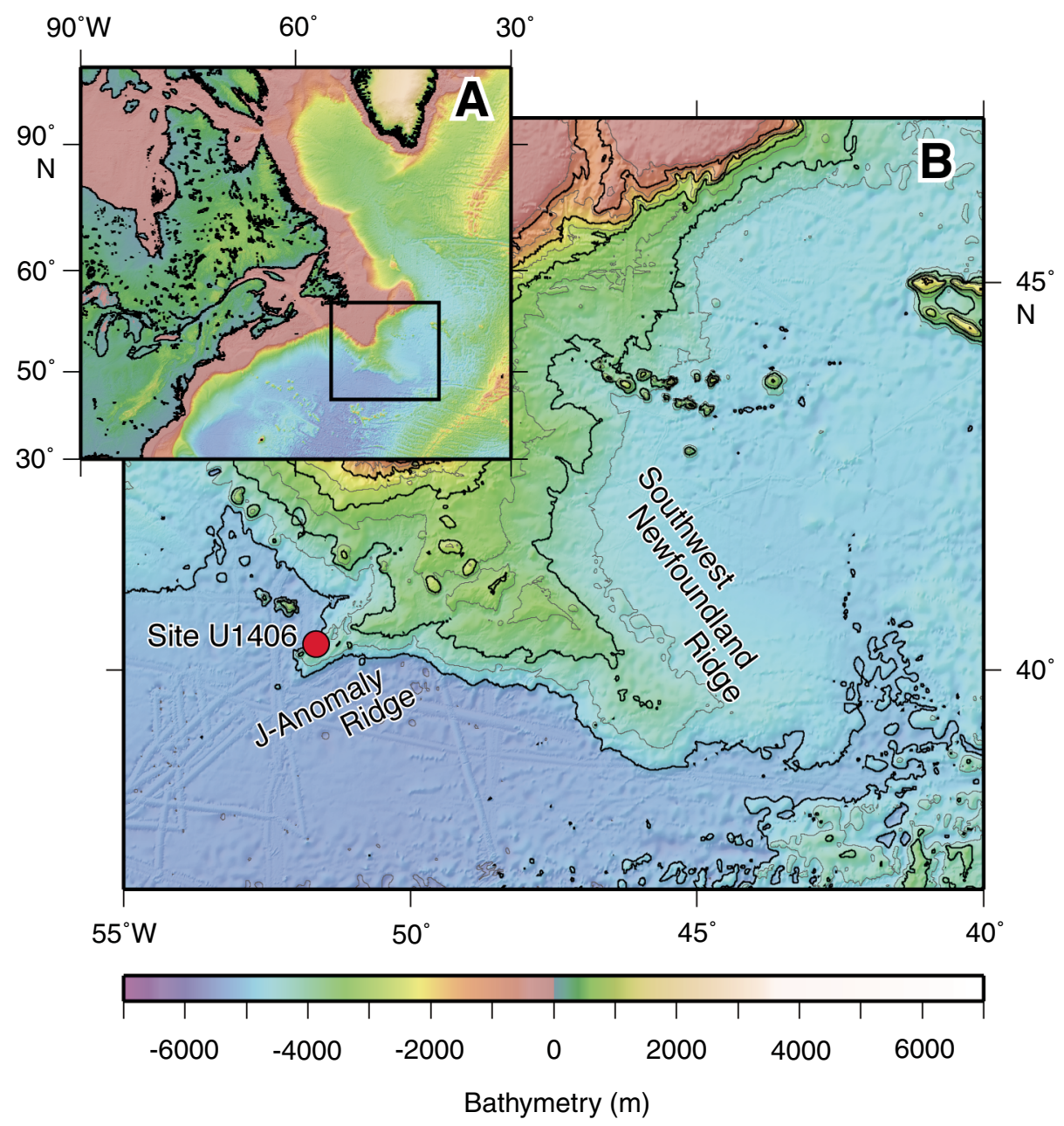


Figure F2. Stratigraphic distribution of preservation and group abundance of benthic foraminifers and relative abundance of each benthic foraminiferal morphotype shown with carbonate content and color reflectance (see the "Site U1406" chapter [Norris et al., 2014c]). Splice: green = Hole U1406A, pink = Hole U1406B, blue = Hole U1406C. Gray shading in the splice and the core distribution in Hole U1406A indicate unrecovered intervals. Green line $=$ preservation, red shading $=$ group abundance .

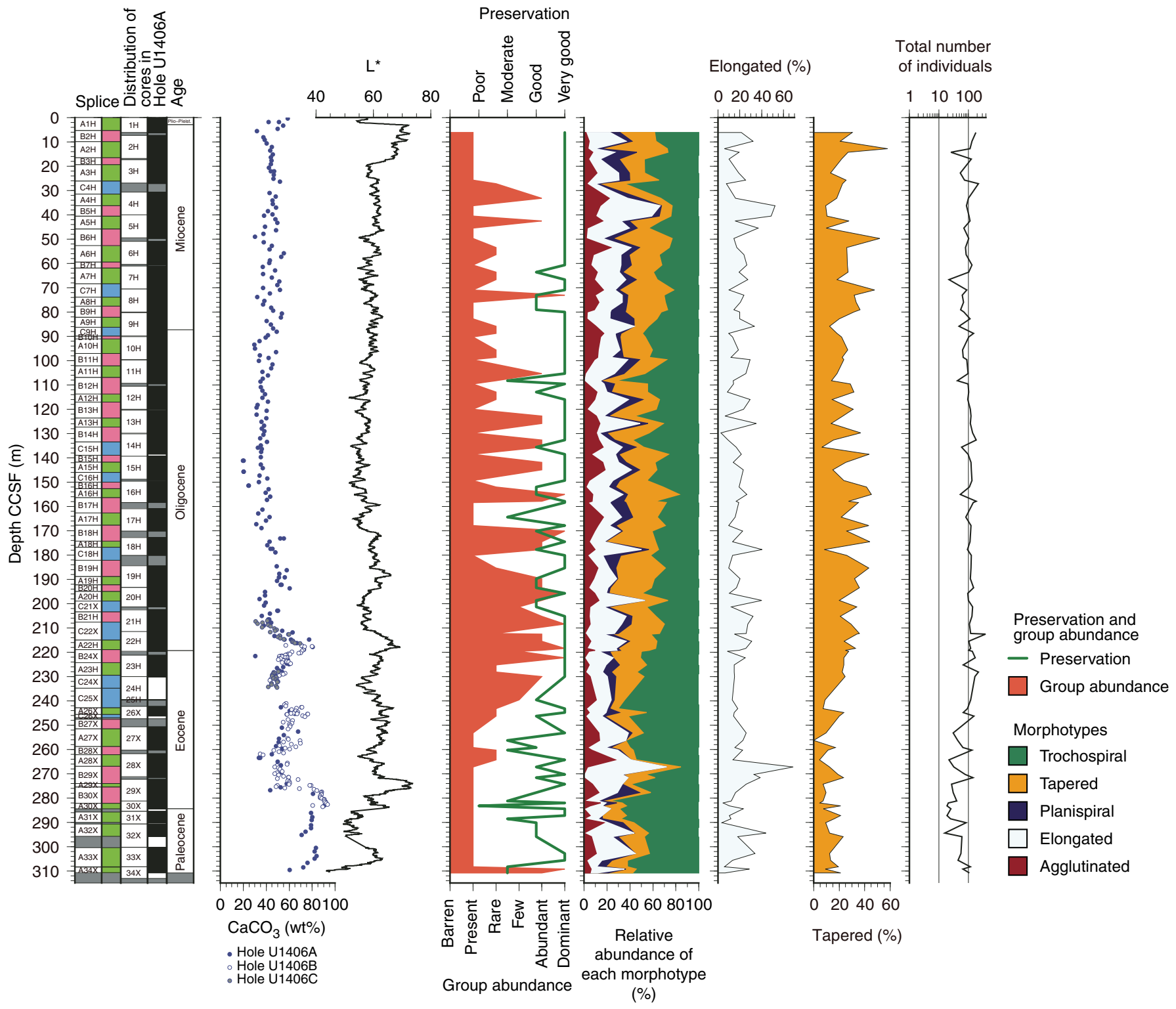


Table T1. Stratigraphic distribution of benthic foraminiferal morphotypes, Hole U1406A. This table is available as an oversized PDF.

Table T2. Main faunal components of the five benthic foraminiferal morphotypes identified in this study.

\begin{tabular}{ll}
\hline \multicolumn{1}{c}{ Morphotype } & \multicolumn{1}{c}{ Main components } \\
\hline Agglutinated & Dorothia sp., Gaudryina sp., Karreriella sp. \\
Elongated & Dentalina sp., Pleurostomella spp., Stilostomella spp.* \\
Planispiral & Lenticulina spp., Nonion sp., Pullenia spp.* \\
Tapered & Aragonia spp., Bulimina spp. Cassidulina spp. *, Fissurina spp., Lagena sp. \\
Trochospiral & Anomalina sp., Anomalinoides spp., Cibicidoides spp., Gyroidinoides spp., Oridorsalis spp. \\
\hline
\end{tabular}

* = dominant species among species listed. 